\title{
Prevalence and Intensity of Trematode Flukes in Different Hair Color of Aceh Cattle
}

\author{
Lian Varis Riandi ${ }^{1 *}$, Ryan Ferdian ${ }^{2}$, Muhammad Hambal ${ }^{1}$ Muttaqien Bakrie ${ }^{1}$ \\ ${ }^{1}$ Laboratory of Parasitology, Faculty of Veterinary Medicine, Syiah Kuala University, Banda Aceh \\ ${ }^{2}$ Laboratory of Clinic, Faculty of Veterinary Medicine, Syiah Kuala University, Banda Aceh \\ *Corresponding author. Email: lianvarisriandi@ unsyiah.ac.id
}

\begin{abstract}
This study aims to determine the prevalence and number of trematode eggs (Fasciola gigantica and Paramphistomum spp) in different hair colorof Aceh cattle. This research used feces collected from 105 cattle in Mesjid Raya Subdistrict, Aceh Besar. The feces samples were divided into 3 groups based on the color of the cattle hair (red, white, and black) and each group consist of 15 male and 20 female cattle. Simple random sampling was used to determine the sample. The number of eggs per gram of feces (TTGT) was determined using Borray modification sedimentation method. The results showed that different haircolor of Aceh cattle revealed different trematode egg number (red 7.02, white 12.2, and black 7.03) and different trematode prevalence rate (red 80\%, white 85.7\%, and black $88.5 \%$ ). In conclusion, the lowest number of trematode parasite eggs in each gram of feces and the lowest prevalence rate was observed in red hair color of Aceh cattle.
\end{abstract}

Keywords: Aceh cattle, Fasciola gigantica, Paramphistomum spp, Hair color, Pparasite intensity

\section{INTRODUCTION}

Aceh cattle were designated as native cattle of Indonesia in 2011 by the Minister of Agriculture of the Republic of Indonesia through the Decree of the Minister of Agriculture No: Kpts/OT.140/6/2011 [1]. Aceh cattle were brought by Indian traders during the first Islamic Kingdom in Peureulak in 847 AD (225 $\mathrm{AH}$ ), since there was already a relationship between countries and free trade in Aceh (Aceh historical records, marcopolo records 1256 and Ibn Bathutah 1345).

Based on the Regulation of the Minister of Agriculture of the Republic of Indonesia No. 54/permentan/ot.140/10/2006 on Good Breeding Practice, Aceh cattle phenotype is defined as light brown, red, brick, dark brown, black and white, gray, black and white color form pattern towards the center of the body. Female has small humped while male has higher hump reaching105 $\mathrm{cm}$ in bulls aged 24-36 months. The results of a survey at several livestock development centers in Aceh show thatthe phenotype characteristic of Aceh cattle have changedthus make it difficult to find criteria as set out above.
Parasites are one type of animal and human diseases which cause detrimental effect to farmers. Such losses occur due to damage to livestock organs and organ systems which in turn cause deaths and economic loss to the farmers. Parasites can also cause harm such aspoor growth and development, low weight gain, organs damaged and poor carcass quality, decreased fertility and increase the predisposition of metabolic diseases. This is due to deficiency of nutrition, changes in water distribution, electrolytes and blood proteins [5].

The prevalence rate of parasites in Aceh cattle in previous research conducted on cows and buffaloes in Lhoong Subdistrict of Aceh Besar District showed a very high rate, especially the intensity of gastrointestinal nematode worms reached $90 \%$ and trematodes worms were between 89-93\% [6]. Many parasitic studies mainly on trematodes and nematodes have been conducted by researchers previously [7], identifying the prevalence of Trematoda in Bali cattle maintained in the Sombangan Village, Bandung Regency. Hambal et al. [6] identified the level of vulnerability of Fasciola gigantica in cattle and buffalo in Lhoong Subdistrict, Aceh Besar Regency. Mubarok et al. [8] examined the prevalence of trematoda in the central Bali Cattle Center in Sombangan Village, 
Bandung Subdistrict. However, research on the prevalence and incidence of parasites based on the phenotype image of Aceh cattle has never been reported. Therefore, the authors wanted to conduct research that relates the color of cattle fur to parasites infestation both the prevalence and number of eggs per gram of feces.

\section{RESEARCH METHODS}

\section{MATERIALS}

AND

\subsection{Research Samples}

Research samples used in this study were feces of Aceh bulls and heifer obtained from the Mesjid Raya Subdistrict, Aceh Besar Regency. Feces samples were collected randomly from 105 cattle (male and female) with different hair color namely red color 35 heads, black color 35 heads and white color 35 heads. Each hair color consists of 15 bulls and 20 heifers.

Approximately 3 grams of fresh cow feces was collected immediately after defecation, thenput in a transparent plastic bag and stored in a cooling container. Each sample was assigned in a sequence number and labeled with the description of the pick-up location, gender, age, and color. Then the samples were examined by Borray modified sedimentation method, which is used for examination of trematodes eggs and identification of worm eggs that have a greater density than water type [6].

\subsection{Research Procedure}

\subsubsection{Borray Modified Sedimentation Method}

Borray's modified sedimentation method was used for examination of trematodes eggs. A total of 3 grams of feces are weighed and put into mortal, diluted with a little water and drip liquid soap then homogenized. The solution was filtered using a sieve in a beaker glass. The remaining material was filtered in high-speed water spray, then let stand for 15 minutes. The supernatan at the top layer was discarded.This method was repeated once more then the remaining sediment was tested with Methylin blue $1 \%$, to distinguish the material derived from plants to trematode eggs, then the remaining sediment was put into a petri dish that has been given square pattern.The number of eggs wascounted per square/boxpatternusing the streo microscope and the number was recorded.

\subsection{Data Analysis}

The data was analyzed using ANOVA followed by Duncan test. The prevalence rate was analyzed by the chi-sguare test, and the number of eggs in males and heifer was compared by using the student t-test.

\section{RESULTS AND DISCUSSION}

Based on the observations of researchers for 53 days in the District of Mesjid Raya Aceh Besar, the ideal locations for sampling are Gampong Paya Kameng and Beurandeh. In these two locations, Aceh cattle population still dominates compared to other gampong and both locations have vast grasslands in hilly areas. This area is surrounded by mountains, grooves that flow water from the mountain and also swamps. The observations during the sampling found that Aceh cattle population in this area is more predominantly consist of red hair cattlethan white and black hair color.

The results of personal communication with farmers in both regions, Aceh cattle have been played a very important role as a source of protein and helping daily work of farmers in the district of Mesjid Raya. Farmers generally prefer Aceh cattle compared to other cattle since Aceh cattle are easy to maintain. The feeding is usually carried out by let the cattle grazing in the pasture (Zainun; personal communication).

\subsection{Examination of Fasciola Gigantica Eggs and Paramphistomum Spp.}

Borray Modified Sedimentation Method is used to examine trematode eggs, thus suitable for the examination of Fasciolosis and paramphistomiasis in a total of 105 feces of Aceh cattle. The results of trematode examination in Aceh cattle based on gender, hair color and prevalence rate are shown in Table 1.

Based on the examination of trematode worm eggs in Aceh cattle in Masjid Raya Sub district, Aceh Besar, the total prevalence of trematoda egg infestation (positive) was $84.7 \%$.The prevalence based on cattle hair color and sex obtained that red heifer have a prevalence of $90 \%$, black heifer $95 \%$, and white heiferof $95 \%$, while the prevalence of trematode eggs in red bull was $66.6 \%$, black bull was $80 \%$, and white bull was $73.3 \%$. The prevalence of trematode egg infestation in Aceh cattle was higher in black hair color cattle $(88.5 \%)$ compared to the white hair color $(85.7 \%)$ and the red one $(80 \%)$. Furthermore, the prevalence of trematode eggs in heifers was higher (93.3\%) than those found in the bulls $(73.3 \%)$.

The data analysis using chi-square test revealed that the prevalence of trematode eggs showed no significant difference $(\mathrm{P}>0.05)$ between bull and heiferand among the hair color. However, the prevalence of trematode eggs in bulls and heifer shows a significant difference $(\mathrm{P}<0.05)$.

The high infestation of trematode in cattle in Mesjid Raya Sub district, Aceh Besar is closely related to the 
maintenance and topographical system of this area, which has a large area of swamps, trenches surrounding the mountain slopes and also former rice fields that are flooded with water. Cattle that are traditionally maintained tend to use rice fields, the fringes of swamps on the outskirts of the trenches to graze and become a source of feed. This area generally has an abundant water source which is generally a habitat for Lymnaea rubiginosa snails. This type of snail is an intermediate host for Fasciola gigantica in Indonesia and other types of trematode, while the intermediate host of Paramphistomum is a snail from the genus of Planorbis planorbis. Suwetta [9] stated that in the traditional farming system, the existence of feed is closely related to the existence of post-harvest grass in the rice fields, above the border of the rice fields, above the river bank, on the edge of swamps and moors which isthe habitat of the intermediate host.

Table 1. The prevalence of Trematode worm eggs in each hair color type from the results of feces examination microscopically.

\begin{tabular}{|c|c|c|c|c|c|}
\hline Color & Gender & $\begin{array}{l}\text { Number } \\
\text { (head) }\end{array}$ & Positive (head) & $\begin{array}{l}\text { Prevalence of } \\
\text { infection (\%) }\end{array}$ & $\begin{array}{l}\text { Total infection } \\
\text { (\%) }\end{array}$ \\
\hline \multirow{2}{*}{ Red brick } & Bulls & 15 & 10 & 66.6 & \multirow{2}{*}{80} \\
\hline & Heifer & 20 & 18 & 90 & \\
\hline \multirow{2}{*}{ Black } & Bulls & 15 & 12 & 80 & \multirow{2}{*}{88.5} \\
\hline & Heifer & 20 & 19 & 95 & \\
\hline \multirow{2}{*}{ White } & Bulls & 15 & 11 & 73 & \multirow{2}{*}{85.7} \\
\hline & Heifer & 20 & 19 & 95 & \\
\hline \multirow{2}{*}{ Total } & Bulls & 45 & 33 & 73.3 & \multirow{2}{*}{84.7} \\
\hline & Heifer & 60 & 56 & 83.3 & \\
\hline
\end{tabular}

Soulsby [10] added that the infestation of tramatodes fasciola gigantica in cattle occurs naturally by eating grass from grazing land contaminated with metasacaria.The infective stage larvae of the worms are attached to the grasses in grazing fields and rice fields, which are ready to infect livestock when eaten the grass.

\subsection{Intensity of Trematoda Eggs in Masjid Raya Subdistrict Aceh Besar}

The examination results of trematode eggs in Aceh cattle of different hair colors in Mesjid Raya sub district, Aceh Besar can be seen in Table 2 .

Table 2. Average number of eggs per 3 grams of feces of each hair color of Aceh cattle

\begin{tabular}{|c|c|c|c|c|}
\hline Color & Sex & $\begin{array}{l}\text { Number of positive } \\
\text { cows (head) }\end{array}$ & $\begin{array}{l}\text { Average number of eggs } \\
\text { per } 3 \text { grams of feces }\end{array}$ & $\begin{array}{l}\text { Total average number of } \\
\text { eggs per } 3 \text { grams of feces }\end{array}$ \\
\hline \multirow{2}{*}{ Brick red } & Bulls & 10 & 33 & \multirow{2}{*}{63.2} \\
\hline & Heifer & 18 & 80 & \\
\hline \multirow{2}{*}{ Black } & Bulls & 12 & 21.75 & \multirow{2}{*}{63.2} \\
\hline & Heifer & 19 & 89.5 & \\
\hline \multirow{2}{*}{ White } & Bulls & 11 & 46.9 & \multirow{2}{*}{110.3} \\
\hline & Heifer & 19 & 147.4 & \\
\hline \multirow{2}{*}{ Total } & Bulls & 33 & 33.27 & \multirow{2}{*}{79.11} \\
\hline & Heifer & 56 & 106.125 & \\
\hline
\end{tabular}

Table 2 shows that the samples of cattle feces from Mesjid Raya Subdistrict, Aceh Besar, from each hair color of Aceh cattle were found paramphistomum spp eggs. and Gigantic Fasciola (Figure 3). The highest average number of eggs revealed in heifer of Aceh cattlewith white hair color(147.47 per 3 grams of 
feces) while the lowest average is found in heifercattlewith black hair color (85.52) and in heifercattle with red brick hair color ( 80 per 3 grams of feces). The average number of eggs per 3 grams of feces in the heifer was 106.125 per 3 grams of feces.

In aceh bull population, from each cattlehair color is obtained that the highest average number of trematode egg is revealed in bulls with white hair color(46.09 per 3 grams of feces), and the lowest average number of eggs in Aceh bulls with black haircolor(21.75 per 3 grams of feces) and in bulls with brick red hair color(33 per 3 grams of feces). The total average number of egg per 3 grams of feces in bulls was 33.27 per 3 grams of feces.

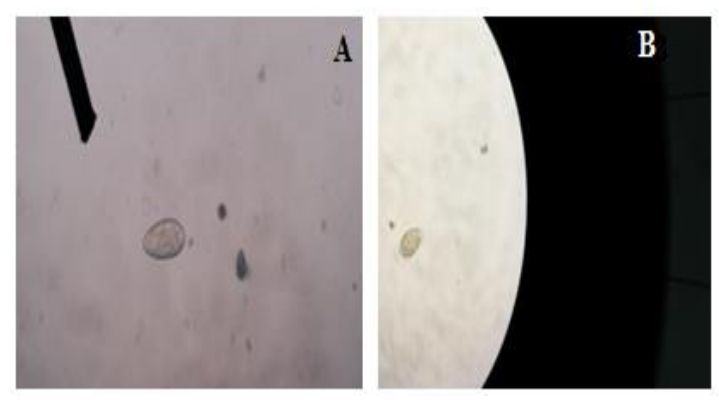

Figure 1 (A) paramphistomum spp egg, (B) Fasciola Gigantica egg

In total, the average number of trematode eggs per 3 grams of feces based on the color of Aceh cattle hair revealed that the highest result is found in Aceh cattle with white hair color (110.3 per 3 grams of feces), while the lowest trematode egg infection was in Aceh cattle with red hair color (63.21 per 3 grams of feces) and followed by the black hair color (63.29 per 3 grams of feces).

The ANOVA test which analyze the effect of hair color on the number of eggs showed no significant difference $(\mathrm{P}>0.05)$. The influence of hair color on the number of eggs based on gender analyzed by $\mathrm{T}$-Test test demonstrated a significant influence $(\mathrm{P}<0.05)$, similar result also occurs on the influence of male and female sex on hair color $(\mathrm{P}<0.05)$.

Researchers assume that the infestation rate of trematode eggs in cattle which traditionally maintained is due to a lack of public understanding in the administration of anthelmintic and the management of cattle rearing including appropriate time to let the cattle grazing in the pasture. This leads to trematode parasites multiply freely in the body of the definitive host.
Table 3. The cattle body scorecondition based on hair color

\begin{tabular}{|l|l|l|l|l|}
\hline $\begin{array}{l}\text { Body } \\
\text { Condition }\end{array}$ & $\begin{array}{l}\text { Red } \\
\text { brick }\end{array}$ & Black & White & Total \\
\hline Good & 10 & 5 & 4 & 19 \\
\hline Medium & 23 & 27 & 24 & 74 \\
\hline Bad & 2 & 3 & 7 & 12 \\
\hline Total & 35 & 35 & 35 & 105 \\
\hline
\end{tabular}

Table 3 explained that the best cattle body scorecondition is shown in a coal-red cattle with a total number of 10 heads and the least is shown in white haircattle that are 4 heads. For medium body conditions, mostly shown in black hair color cattle with a total of 27 heads, and the fewest shows in cattle with red brick hair color as many as 23 heads. While the poor body score condition is demonstrate in white hair color cattle with the most number of 7 heads, and the least red brick cattle was only 2 heads.

Table 4. Skin health and the presence of externa parasites based on hair color.

\begin{tabular}{|l|l|l|l|l|}
\hline $\begin{array}{l}\text { Skin } \\
\text { externa } \\
\text { parasites }\end{array}$ & $\begin{array}{l}\text { Red } \\
\text { brick }\end{array}$ & Black & White & Total \\
\hline High & 0 & 0 & 2 & 2 \\
\hline Medium & 17 & 25 & 24 & 66 \\
\hline Low & 18 & 10 & 9 & 37 \\
\hline Total & 35 & 35 & 35 & 105 \\
\hline
\end{tabular}

From the table above it can be seen that the health condition of Aceh cattle skin/ the occurrence of external parasites was high with the number of 2 heads, medium skin condition was found in 66 heads and low skin condition was observed in 37 cattle. The condition of the skin is reviewed from the presence of external parasites, thus, red brick hair color cattle is in the best condition, while white hair color cattle is the most experienced poor skin condition.

\section{CONCLUSION}

Based on the results of the study it can be concluded that:

1. Black hair color of Aceh cattle have the highest prevalence rate of trematodes $(88.5 \%)$, while redbrick hair color cattle have the lowest prevalence rate $(80 \%)$. 
2. There is a difference in eggs per gram of feces (EPG), in heifer 11.7 and in bulls 3.69.

3. The lowest number of trematode eggs per grams of feces found in the red hair color of Aceh cattle.

\section{AUTHORS' CONTRIBUTIONS}

All authors were equally involved in the manuscript preparation and had read and were agree with the final version of the paper.

\section{ACKNOWLEDGMENT}

The author thanked all members of this research team as well as the research adviser Dr. Drh. Muhammad Hambal so that this research went smoothly.

\section{REFERENCES}

[1] Jamaliah. 2010. Pelestarian Plasma Nutfah Sapi Aceh. Balai Pembibitan Ternak Unggul (BPTU) Sapi Aceh Indrapuri, Banda Aceh.

[2] M.A.N. Abdullah, R.R. Noor, H. Martojo, D.D. Solihin, Karakteristik genetik sapi Aceh dengan menggunakan DNA mikrosatelit. J. Indones. Trop. Anim. Agric. 33(3) (2008) 63-74.

[3] R.R. Noor, Genetika Ternak. Penerbit Swadaya, Jakarta, 2008.

[4] T. Armansyah T.R., A. Azhar, T.N. Siregar, Analisis isozim untuk mengetahui variasi genetik sebagai upaya pemurnian ras sapi Aceh, J. Vet. 12(4) (2012) 254-262.

[5] Anderson, Weller, Veteinary Medicine. Bailliere Tindall, London, 1983

[6] M. Hambal, A. Sayuti, A. Dermawan, Tingkat kerentanan Faciola gigantica pada sapi dan kerbau di kecamatan Lhoong kabupaten Aceh Besar. Jurnal Medika Veterinaria 7(1) (2013) 4953. DOI: https://doi.org/10.21157/j.med..v7i1.2921

[7] R.D. Putra, N.A. Suratma, I.B.M. Oka, Prevalensi trematoda pada sapi Bali yang dipelihara peternakan di desa Sobangan, kecamatan Mengwi, Kabupaten Bandung. Indonesia Med. Vet. 3(5) (2015) 394-402.

[8] F. Mubarok, N.A. Suratman. I. Dwinata, Prevalensi trematoda di sentra pembibitan sapi Bali desa Sabongan. Kecamatan Mengwi. Kabupaten Bandung. Indonesia Med. Vet. 4(1) (2015) 48-53.

[9] I.G.P. Suweta, Ekonomi oleh cacing hati pada sapi Bali sebagai implikasi interaksi dalam lingkungan hidup pada ekosistem pertanian di Bali. Disertasi, Universitas Padjadjaran, Bandung, 1982.

[10] E.J.L. Soulsby, Helminths, Arthropods and protozoa of domesticated animal. The English Language Book Society and Balliere Tindall, London, 2005. 